\title{
Suriyeli Sığınmacı Kamplarının Bulunduğu İlçelerde Çalışan Sağlık Personelinin İş Stres Seviyesi: Şanlıurfa Örneği
}

Job Stress Levels of Healthcare Professionals Working in the Districts Located Near Syrian Refugee Camps: Case of Şanlıurfa

\author{
Hüseyin ERIȘ 1 (D) Suzan HAVLIOĞLU 1 \\ 1 Harran Üniversitesi, Sağlık Hizmetleri Meslek Yüksekokulu, Şanlıurfa, Türkiye
}

öz.

Amaç: Bu çalışmanın amacı, Şanlıurfa'nın Suriye sınıına yakın ilçelerindeki devlet hastaneleri ve kamplarda çalışan sağlık personelinin iş stresi seviyelerini tespit etmektir.

Materyal ve Metod: Araştırma, Şanlıurfa'nın Suriye sınırında bulunan ve Suriyeli göçmenler için oluşturulan kampların bulunduğu Suruç, Harran, Akçakale, Viranşehir ve Ceylanpınar ilçelerindeki Kamu Hastaneleri Kurumuna bağlı bulunan 5 devlet hastanesinde çalışan toplam 670 sağlık çalışanına 01.04.2016 - 15.08.2016 tarihleri arasında İş Stresi Ölçeği uygulanarak yapılmıştır. Araştırmanın evrenini oluşturan 670 sağlık çalışanından 448'i (\%67) bu çalışmaya katımıştır.

Bulgular: Araştırmanın Cronbach's Alpha değeri 0,885 tespit edilmiştir. Boyuttaki maddeler için Cronbach's alpha katsayısına göre elde edilen verilerin güvenirliğinin yüksek düzeyde olduğu görülmektedir. Araştırma sonucunda, İş stresi ölçeğinde, ilçe Devlet Hastanelerine göre İş Baskısı $(p=0,000)$ ve Örgütsel Destek eksikliği $(p=0,000)$ alt boyutlarında istatistiksel olarak anlamlı bir ilişki olduğu tespit edilmiştir. İş baskısı alt boyutunun ortalaması $(3,76 / 5)$, Örgütsel Destek eksikliği alt boyutunun ortalaması ise $(3,79 / 5)$ olarak bulunmuştur. Araştırmanın iş baskısı ve Örgütsel Destek eksikliği alt boyutlarında; yaş, eğitim, meslek gruplarında istatistiksel olarak anlamlı farklıık olduğu tespit edilmiştir. Cinsiyet değişkeni açısından istatistiksel olarak anlamlı bir farkııık tespit edilmemiştir.

Sonuç: Bu çalışmayı Türkiye'nin Suriye'ye sınırı olan bütün ilçelerindeki sağlık çalışanlarına genelleme yapamayız. Bu sebepten, bu araştırma önce yapılan sağlık personellerinin iş tükenmişlik durumlarının tespit edilmesi ile ilgili çalışmalarla karşılaştırma yapmak açısından ve bundan sonra bu konu ile ilgili çalışma yapacaklar için yararlı olabilir.

Anahtar Kelimeler: Sağlık personeli, İ̧ Stresi, Suriyeli Sığınmacı

\section{Abstract}

Background: The objective of this study is to determine job stress levels of healthcare professionals working in public hospitals and camps in the districts near the Syria border in Şanlıurfa.

Materials and Methods: The study was conducted on a total of 670 healthcare professionals working in 5 public hospitals affiliated with the Public Hospitals Administration in the districts of Suruç, Harran, Akçakale, Viranşehir and Ceylanpınar located near the Syria border in Şanlıurfa and hosting the camps of Syrian refugees by applying the Job Stress Survey between 01.04.2016 and 15.08.2016. 448 of 670 healthcare professionals constituting the population of the study participated in the study.

Results: Cronbach's Alpha value of the survey was determined as 0.885 . As a result of the study, it was determined that there was a statistically significant correlation in the subscales of Job pressure and Lack of Organizational Support in the Job Stress Surveyin terms of district Public Hospitals. While the mean score of the subscale of Job pressure was determined as the mean score of the subscale of Lack of Organizational Support was determined as. There was a statistically significant difference in age, education, and occupational groups in the subscales of Job pressure and Lack of Organizational Support in the study. On the other hand, no statistically significant difference was found in terms of the variable of gender.

Conclusion: Thus, this study may be useful primarily for making a comparison with studies aimed at determining job burnout of healthcare professionals and conducting further related studies.

Keywords: Healthcare professional, Job Stress, Syrian refugee
Sorumlu Yazar $I$

Corresponding Author

Dr. Hüseyin ERiş

Harran Üniversitesi,

Sağlık Hizmetleri Meslek Yüksekokulu, Şanlıurfa, Türkiye

Tel:+905325664872

E-mail:erisharran@hotmail.com

Geliş tarihi / Received:28.12.2018

Kabul tarihi / Accepted: 10.05.2019

DOI: 10.35440/hutfd.504875

Bu çalışma International Conference on Social and Related Sciences'de (4-8 October 2017) Sözel Bildiri olarak sunulmuştur. 


\section{Giriş}

21. yüzyıldaki küreselleşme, ekonomik krizler, teknoloji ve bilişim alanındaki hızlı gelişmeler, insanların yaşam tarzında ciddi değişimlere neden olmaya başlamıştır. Bu değişimler insanların önceliklerini, tercihlerini belirlemede önemli bir yol gösterici konumundadır (1). Politik çatışmalar ve savaşlar, artan işsizlik oranı, sosyo kültürel çatışmalar, yoğun ve ağır çalışma koşulları gibi nedenlerden dolayı insanlar stres faktörü ile karşı karşıya kalmakta ve bu faktörle yaşamaya çalışmaktadır (2-4).

Stres konusu, birçok farklı bilim alanında araştırma yapan kişi, kurum ve kuruluş tarafından sürekli olarak nedenleri, kapsamı, sonuçları incelenmekte ve stresle mücadele yolları araştırılmaktadır (1).

Stresin çok sayıda tanımı bulunmaktadır. Latince "estrica" sözcüğünden dilimize geçen "stres"; insanların sağlığı ve huzuru için bir tehlike işareti, bir uyarı olarak algılanan ve dolayısıyla yetersiz bir şekilde ele alınan olaylara gösterilen, belirgin olmayan fizyolojik ve psikolojik tepkileri ifade etmektedir (5). Başka bir tanımda stres; organizmanın bedensel ve ruhsal sınırlarının tehdit edilmesi ve zorlanması ile ortaya çıkan, çeşitli fiziksel ruhsal belirtiler gösteren bir durum olarak tanımlanmıştır (6).

Mesleki araştırmalar, yüksek seviyedeki stres ile personelin iyi olma durumu, verimliliği ve sağlığı üzerindeki ilişkiyi belirlemişlerdir (7). İş hayatı boyunca, tüm çalışanlar iç ve dış koşullar sebebiyle stresle karşı karşıya kalmaktadırlar. Uzun süre strese maruz kalanlarda çeşitli psikolojik ve bedensel sorunlar ortaya çıkmaktadır. Birey, stres faktörüyle baş edebiliyorsa, gerilimden uzak kalıyor demektir. Eğer stres faktörüyle baş edemiyorsa, stres faktörü karşısında bireyde fiziksel ve psikolojik sorunlar çıkmaya başlar. Bu durumun sürekli olması durumunda tükenmişlik durumu ya da stresle ilgili diğer hastalıklar gelişebilir (2, 8).

Sağılı kurumlarında, duygusal açıdan zayıf olan hasta ve yakınlarına hizmet verilirken, bu hizmeti sunan sağlık personelinin stres seviyeleri, diğer sektörlerde çalışan personelden daha fazla olarak değerlendirilmekte ve sağlık kurumlarındaki stresörlerin, sağlık çalışanlarının beden ve ruh sağlığını ve iş doyumunu olumsuz etkilediği belirtilmektedir (9-11).

\section{İs Stresi}

Çağımızın hastalığı olan stress, çalışanlar üzerinde oluşturduğu olumsuz etki ile örgütü de etkilemektedir. Stres faktörünün bireyler üzerindeki fizyolojik, psikolojik ve davranışsal etkileri son yıllarda yapılan araştırmalarla ortaya konmaktadır $(2,7,12)$. İs stresi, bireyin yeteneklerindeki yetersizliklere, fiziksel ya da psikolojik nedenlere bağlı olarak ortaya çıkan ve bireyde gerilim yaratan durum olarak tanımlanmaktadır $(3,13)$. İşyeri stresi günümüzde çalışanları büyük ölçüde etkilerken, iş stresinin önemi pek çok araştırmayla da desteklenmektedir $(4,14)$. İş, insan yaşamı içinde önemli bir yer tutmaktadır. Çalışı- lan işyeri ile ilgili olumsuz faktörler çalışanlar üzerinde fizyolojik, psikolojik baskılar ve yıkımlar oluşturduğu, onların sağlık ve başarılarını olumsuz yönde etkilediği araştırmalarla da tespit edilmiş bulunmaktadır. Özellikle işgücü devrini artırma, işe devamsızık, işten ayrıma isteği ve tükenmişlik en önemli nedenlerinden biri olduğu bilinmektedir $(2,4)$. Çalışanların birinde görülen stresin diğer çalışanları da etkilediği ve çalışanların tümünün güvenliğini tehdit edebildiği, iş kazalarına yol açabildiği anlaşılmaktadır (15).

İ̧ ve stres arasındaki ilişkiler, araştırmacıları iş stresi ve meslek stresi ile ilgili araştırmalara sevk etmiştir. Örneğin yönetici, polis, asker, hemşire gibi bazı mesleklerin stres düzeyini, yollarını, mücadele tekniklerini bilimsel olarak ele alan ve inceleyen birçok araştırmalar vardır (2). Araştırmalar sonucu, çalışan bireylerin özel yaşamlarından kaynaklanan stresin yanı sıra, mesleki kimlikleri, rol yükü, kişiler arası ilişkilerden kaynaklanan gerilimi, kariyer bekIentisi, işyeri sorunları, yetersiz kaynak ve kurumsal katkı, rol çatışmaları vb. birçok potansiyel stres kaynağının çalışanların sağıı̆ını tehdit ettiği anlaşılmaktadır (15).

İş stresi ili ilgili yapılan araştırmalarda, iş stresinin çalışan personel arasında tatmin duygularını azaltma, işe yabancılaşma, düşük verimlilik, personelin işe gelmemesi gibi işletmeler açısından da sorunlara neden olduğunu göstermektedir. Stresli bir ortamda çalışanların sağlıksız, az motivasyonlu, daha az üretken ve iş yerinde daha $a z$ güvenli olmasının olasılığı artmaktadır $(11,16)$.

Farklı meslek kuruluşları, medya, sendikalar ve giderek artan sayıda araştırmacıların yaptıkları çalışmalar mesleki stresin insan ve finansal açıdan yüksek maliyeti olduğunu ortaya koymuşlardır (1). Stressin, işyeri üzerinde verimlilik, devamsızlık, çalışan devir hızı, iş̧̧i sağlığı ve iyi olma gibi olumsuz etkileri vardır (2).

Sağılık çalışma ortamlarındaki iş stresi nedenleri Tel ve Arkadaşları tarafından şu şekilde belirlenmiştir; sağlık bakım yaklaşımları ve organizasyon değişiklikleri sonunda ortaya çıkan yeni uygulama ve beklentiler, çalışma orta$\mathrm{mI}$, iş yükünün fazla olması, kişilerarası ilişki sorunları, yoğun bakım gerektiren veya ölmek üzere olan hasta ile çalışma (10).

İşyeri koşulları yanında, kişinin genel sağlığını bozabilen kötü çalışma koşulları, yapılan iş, işlem ve tüm uygulamalarda bitkinlik, bezginlik ve yorgunluk gibi zorlamalara neden olan tüm faktörler fiziksel ve psikolojik zedelenmelere neden olabilmektedir. İ̧ yaşamında stresle ilgili hastalıkların her geçen gün daha fazla artması ve stresin iş hayatında verim düşüklüğü, işe devamsızlık, sağlık sigortaları ödemelerinin artması, personel devir hızındaki artış, hırsızlık ve sabotaj gibi olumsuz sonuçlara yol açması onun bireyler ve örgütler üzerinde ne kadar önemli olduğunu göstermektedir (17). Diğer bir ifade ile çalışan bireylerin stresle karşılaşması kaçınılmazdır.

İş stresi, doğrudan gözlem, mülakat ve 'iş Stresi Ölçeği, 
(JSS) (8), 'Mesleki Stres Göstergesi' (18) ve 'Mesleki Stres Envanteri' (19) gibi anket/ölçekler kullanılarak belirlenebilmektedir.

Bu çalışmanın amacı, Şanlıurfa'nın Suriye sınırına yakın ilçelerindeki devlet hastaneleri ve kamplarda çalışan sağlık personelinin iş stres düzeyleri ile sosyo demografik özellikleri açısından gruplar arasından farklılık olup olmadığını belirlemektir.

\section{Materyal ve Metod}

Araşıırmanın Amacl: Bu çalışmanın amacı, Şanlıurfa'nın Suriye sınırına yakın ilçelerindeki devlet hastaneleri ve kamplarda çalışan sağlık personelinin iş stresi durumlarını belirlemektir.

Araştırmanın Evren ve Örneklemi: Araştırmanın evrenini, Şanlıurfa'nın Suriye sınırında bulunan ve Suriyeli göçmenler için oluşturulan kampların bulunduğu Suruç, Harran, Akçakale, Viranşehir ve Ceylanpınar ilçelerindeki Kamu Hastaneleri Kurumuna bağlı bulunan 5 devlet hastanesinde çalışan toplam 670 sağlık çalışanı oluşturmaktadır. Bu hastanelerdeki sağlık çalışanları hem hastanelerde hem de nöbet usulü bu 5 ilçedeki kamplarda görev yapmaktadırlar. Araştırma, 01.04.2016 - 15.08.2016 tarihleri arasında Vagg ve Spilerberg (1999) tarafindan geliştirilen "Job Stress Survey (JSS)/ İş Stresi" ölçeğini kullanarak yapılmıştır. Araştırma yapılmadan önce Harran Üniversitesi Etik Kurulundan etik kurulu onayı ile çalışmanın yapılacağı ilçe kamu hastanelerinin bağlı bulunduğu Kamu Hastaneleri Şanlıurfa Genel Sekreterliğinden gerekli izin yazıları alınmıştır. Araştırmanın evrenini oluşturan 670 sağlık çalışanından 448'i (\%67) bu çalışmaya katımıştır.

Veri Toplama Aracı: Kesitsel tipteki bu çalışma, 2 bölümden oluşmaktadır. Birinci bölümde, araştırmacılar tarafından hazırlanan, sağlık personeli ile ilgili demografik ve mesleki özellikleri belirlemeye yönelik sorular bulunmaktadır. Çalışmanın ikinci bölümünde ise Vagg ve Spielberger(1999) tarafından geliştirilen iş stresi ölçeği (JSS) kullanılmıştır. Ankette yer alan her bir ifade $5^{\prime}$ li Likert ölçeğine göre hazırlanmış olup; "Hiçbir Zaman (1)", "Çok Nadir (2)", "Bazen (3)", "Çoğu Zaman (4)" ve "Her zaman (5)" ifadeleri yer verilerek oluşturulmuştur.

Araştırmanın Varsayımları: Araştırma, Türkiye geneli bir çalışma olmayıp, sadece araştırmanın yapıldığı Şanlıurfa'nın Suriye sınııında bulunan ve Suriyeli göçmenler için oluşturulan kampların bulunduğu Suruç, Harran, Akçakale, Viranşehir ve Ceylanpınar ilçelerindeki Kamu Hastaneleri Kurumuna bağlı bulunan 5 devlet hastanesinde çalışan sağlık personelinin görüşlerini yansıtmaktadır. Araştırmaya, kamp bulunmayan diğer ilçe hastaneleri dahil edilmemiştir. Bunun yanı sıra, bu araştırmada elde edilen sonuçların, genel olarak gelecekte yapılacak araştırmalara, hastane yöneticilerine ve sağlık politikacılarına bilgi sağlayabileceği varsayılmaktadır. Araştırmaya katılan sağlık personelinin araştırmadaki ifadeleri doğru anladıkları ve doğru cevap verdikleri kabul edilmektedir.

Araştırmanın Geçerlilik ve Güvenirliliği: Bir araştırmada kullanılan ilgili ölçeğin alfa katsayısı ne kadar yüksek olursa "bu ölçekte bulunan maddelerin o ölçüde birbiriyle tutarlı ve aynı özelliğin öğelerini yoklayan maddelerden oluştuğu ya da tüm maddelerin o ölçüde birlikte çalıştığı" yorumu yapılır. Araştırmada kullanılan ölçeğin cronbach alfa katsayısı, 0,884 olarak bulunmuştur. Ölçeğe ait iş baskısı alt boyutunun cronbach alfa katsayısı 0,882 ; örgütsel destek eksikliği alt boyutunun ise 0,885 olarak tespit edilmiştir. Bu değerlere baktığımızda araştırmada kullanılan ölçeğin güvenirlilik değerlerinin yüksek olduğunu söyleyebiliriz.

\section{Bulgular}

Araştırmanın bu bölümünde bağımsız değişkenler ile araştırmada kullanılan bağımlı değişkenler arasındaki ilişki değerlendirilmiştir.

Tablo 1'de ankete katılan sağık personelinin demografik bilgileri verilmiştir.

Tablo 1. Ankete Katılan Sağlık Personelinin Demografik Bilgileri

\begin{tabular}{|c|c|c|c|c|c|}
\hline Hastane & Sayı & Yüzde & Eğitim durumu & Sayı & Yüzde \\
\hline Harran & 51 & 11,4 & Lise & 73 & 16,3 \\
\hline Ceylanpınar & 77 & 17,2 & Önlisans & 94 & 21,0 \\
\hline Viranşehir & 157 & 35,0 & Lisans & 207 & 46,2 \\
\hline Suruç & 79 & 17,6 & Lisansüstü & 5 & 1,1 \\
\hline Akçakale & 84 & 18,8 & Tıp /Uzman hekim & 69 & 15,4 \\
\hline Toplam & 448 & 100,0 & Toplam & 448 & 100,0 \\
\hline Yaş grupları & Sayı & Yüzde & Meslek & Sayı & Yüzde \\
\hline 24 yaş ve altı & 116 & 25,9 & Hekim & 74 & 16,5 \\
\hline $25-27$ yaş & 130 & 29,0 & Hemşire-ebe & 258 & 57,6 \\
\hline $28-32$ yaş & 101 & 22,5 & Sağlık teknisyeni-teknikeri & 106 & 23,7 \\
\hline 33 yaş ve üstü & 101 & 22,5 & Diğer & 10 & 2,2 \\
\hline Toplam & 448 & 100,0 & Toplam & 448 & 100,0 \\
\hline Cinsiyet & Sayı & Yüzde & & & \\
\hline Kadın & 216 & 48,2 & & & \\
\hline Erkek & 232 & 51,8 & & & \\
\hline Toplam & 448 & 100,0 & & & \\
\hline Medeni durum & Sayı & Yüzde & & & \\
\hline Evli & 159 & 35,5 & & & \\
\hline Bekar & 271 & 60,5 & & & \\
\hline Boşanmış & 18 & 4,0 & & & \\
\hline Toplam & 448 & 100,0 & & & \\
\hline
\end{tabular}

Araştırma yapılan hastanelerdeki sağlık çalışanlarının \%11,4'ü Harran, \%17,2'si Ceylanpınar, \%35'i Viranşehir, \%17,6'sı Suruç ve \%18,8'i Akçakale Devlet Hastanelerinde çalışmaktadır. Yaş grupları açısından \%25,9'u 24 yaş ve altı, \%29'u 25-27 yaş, \%22,5'i 28-32 yaş ve \%22,5'i isi 33 yaş ve üstü grubunda yer almaktadır. Araştırmaya 
katılan sağlık personelinin \%48,2'si kadın, \%51,8'i erkek; $\% 35,5$ 'i evli, \%60,5'i bekar ve \%4'ü boşanmıştır. Eğitim durumu bakımından \%46,2'si lisans, \%21'i Önlisans, \%16,3'ü lise, \%15,4'ü Uzman hekim, \%1,1'i lisansüstüdür. Meslek değişkeni açısından sağlık çalışanlarının \%16,5'i hekim, $\% 57,6$ 'sı hemşire/ebe, $\% 23,7$ 'si sağlık teknisyeniteknikeridir.

Tablo 2'de, stres boyutlarının ilçe hastane değişkeni bakımından incelenmesi verilmiştir.

Tablo 2. Stres Boyutlarının İlçe Hastane Değişkeni Bakımından İncelenmesi

\begin{tabular}{|c|c|c|c|c|c|c|}
\hline & İlçe Hastaneleri & $\mathrm{N}$ & Ort. & Std.Sapma & $\mathbf{F}$ & $p$ \\
\hline \multirow[t]{6}{*}{ İş baskısı } & Harran & 51 & 3,66 & 0,719 & \multirow{6}{*}{9,936} & \multirow{6}{*}{$0,000^{*}$} \\
\hline & Ceylanpınar & 77 & 3,33 & 0,928 & & \\
\hline & Viranşehir & 157 & 3,89 & 0,787 & & \\
\hline & Suruç & 79 & 3,65 & 0,799 & & \\
\hline & Akçakale & 83 & 4,08 & 0,865 & & \\
\hline & Toplam & 447 & 3,76 & 0,855 & & \\
\hline \multirow[t]{6}{*}{ Örgütsel Destek Eksikliği } & Harran & 51 & 3,71 & 0,734 & \multirow{6}{*}{9,133} & \multirow{6}{*}{$0,000^{*}$} \\
\hline & Ceylanpınar & 77 & 3,38 & 0,861 & & \\
\hline & Viranşehir & 157 & 3,95 & 0,773 & & \\
\hline & Suruç & 79 & 3,65 & 0,790 & & \\
\hline & Akçakale & 83 & 4,10 & 0,857 & & \\
\hline & Toplam & 447 & 3,79 & 0,833 & & \\
\hline
\end{tabular}

Stres ölçeği boyutlarının çalışılan hastane değişkeni bakımından incelenmesi Tablo 2'de verilmiştir. Incelenen boyutlarda çalışılan hastane değişkeni bakımından istatistiksel olarak anlamlı farklılık olup olmadığı ANOVA testi ile araştırımıştır. Yapılan istatistiksel test sonucunda alt boyutların ikisinde de çalışılan hastane değişkeni bakımından istatistiksel olarak anlamlı fark bulunmuştur. Farklıığın kaynağını belirlemek için Tukey testi uygulanmış ve aşağıdaki bulgular elde edilmiştir.

i. İs baskısı boyutunda farklılığın Harran ile Akçakale, Ceylanpınar ile Viranşehir, Ceylanpınar ile Akçakale ve Suruç ile Akçakale devlet hastanelerinin ortalamalarının farklı olmasından kaynaklandığı görülmüştür.

ii. Örgütsel destek eksikliği boyutunda ise farklılığın Ceylanpınar ile Viranşehir, Ceylanpınar ile Akçakale ve Suruç ile Akçakale devlet hastanelerinin ortalamalarının farklı olmasından kaynaklandığı görülmüştür.

Tablo 3'de, stres boyutlarının yaş grupları değişkeni bakımından incelenmesi verilmiştir.
Tablo 3. Stres Boyutlarının Yaş Grupları Değişkeni Bakımından İncelenmesi

\begin{tabular}{|c|c|c|c|c|c|c|}
\hline \multirow{6}{*}{ Iş baskısı } & & $\mathrm{N}$ & Ort. & Std.Sapma & \multirow{6}{*}{$\begin{array}{l}\mathbf{F} \\
8,120\end{array}$} & \multirow{6}{*}{$\frac{\mathbf{p}}{0,000^{*}}$} \\
\hline & 24 yaş ve altı & 115 & 3,95 & 0,805 & & \\
\hline & $25-27$ yaş & 130 & 3,90 & 0,776 & & \\
\hline & $28-32$ yaş & 101 & 3,69 & 0,816 & & \\
\hline & 33 yaş ve üstü & 101 & 3,45 & 0,954 & & \\
\hline & Toplam & 447 & 3,76 & 0,855 & & \\
\hline \multirow[t]{5}{*}{ Örgütsel Destek Eksikliği } & 24 yaş ve altı & 115 & 3,97 & 0,783 & \multirow[t]{5}{*}{5,286} & \multirow[t]{5}{*}{$0,001^{*}$} \\
\hline & $25-27$ yaş & 130 & 3,87 & 0,785 & & \\
\hline & 28-32 yaş & 101 & 3,70 & 0,783 & & \\
\hline & 33 yaş ve üstü & 101 & 3,56 & 0,937 & & \\
\hline & Toplam & 447 & 3,79 & 0,833 & & \\
\hline
\end{tabular}

Stres ölçeği boyutlarının yaş grupları değişkeni bakımından incelenmesi Tablo 3'de verilmiştir. İncelenen boyutlarda yaş grupları değişkeni bakımından istatistiksel olarak anlamlı farkılık olup olmadığı ANOVA testi ile araştırılmıştır. Yapılan istatistiksel test sonucunda boyutların ikisinde de yaş grupları değişkeni bakımından istatistiksel olarak anlamlı fark bulunmuştur. Farklılı̆ın kaynağını belirlemek için Tukey testi uygulanmış, her iki boyutta da farklıı̆ın 24 yaş ve altı ile 33 yaş ve üstü ve 25-27 yaş ile 33 yaş ve üstü yaş gruplarının ortalamalarının farklı olmasından kaynaklandığı görülmüştür.

Tablo 4'de, stres boyutlarının cinsiyet değişkeni bakımından incelenmesi verilmiştir.

Tablo 4. Stres Boyutlarının Cinsiyet Değişkeni Bakımından İncelenmesi

\begin{tabular}{|c|c|c|c|c|c|c|}
\hline & Cinsiyet & $\mathrm{N}$ & Ort. & Std. Sapma & $t$ & $p$ \\
\hline \multirow[t]{3}{*}{ İş baskısı } & Kadın & 215 & 3,82 & 0,845 & 1,460 & 0,145 \\
\hline & Erkek & 232 & 3,70 & 0,862 & & \\
\hline & Toplam & 447 & 3,77 & 0,854 & & \\
\hline \multirow[t]{3}{*}{ Örgütsel Destek Eksikliği } & Kadın & 215 & 3,86 & 0,826 & 1,798 & 0,073 \\
\hline & Erkek & 232 & 3,72 & 0,834 & & \\
\hline & Toplam & 447 & 3,79 & 0,830 & & \\
\hline
\end{tabular}

Stres ölçeği boyutlarının katılımcının cinsiyeti değişkeni bakımından incelenmesi Tablo 4'de verilmiştir. İncelenen boyutlarda cinsiyet değişkeni bakımından istatistiksel olarak anlamlı farklılık olup olmadığı student $t$ testi ile araştırılmıştır. Yapılan istatistiksel test sonucunda boyutların ikisinde de cinsiyet değişkeni bakımından istatistiksel olarak anlamlı fark bulunamamıştır. Ortalamalar incelendiğinde, boyutların ikisinde de kadın çalışanların ortalamasının daha yüksek olduğu görülmektedir.

Tablo 5'de stres boyutlarının eğitim durumu değişkeni bakımından incelenmesi verilmiştir. 
Tablo 5. Stres Boyutlarının Eğitim Durumu Değişkeni Bakımından İncelenmesi

\begin{tabular}{l|llllll}
\hline \multicolumn{2}{l|}{} & \multicolumn{7}{c}{ N } & Ort. & Std. Sapma & $\mathbf{F}$ & p \\
\hline İş baskısı & Lise & 73 & 3,74 & 0,891 & 3,653 & $0,013^{*}$ \\
& Önlisans & 93 & 3,53 & 0,884 & & \\
& Lisans & 207 & 3,88 & 0,812 & & \\
& Tip & 69 & 3,78 & 0,842 & & \\
\hline Örgütsel Destek Eksikliği & Toplam & 442 & 3,77 & 0,853 & & \\
& Lise & 73 & 3,80 & 0,851 & 4,376 & $0,005^{*}$ \\
& Önlisans & 93 & 3,54 & 0,840 & & \\
& Lisans & 207 & 3,91 & 0,792 & & \\
& Tip & 69 & 3,77 & 0,842 & & \\
& Toplam & 442 & 3,79 & 0,829 & & \\
& & & & & & \\
\hline
\end{tabular}

Stres ölçeği boyutlarıın eğitim durumu değişkeni bakımından incelenmesi Tablo 5'da verilmiştir. Incelenen boyutlarda eğitim durumu değişkeni bakımından istatistiksel olarak anlamlı farklılık olup olmadığı ANOVA testi ile araştırımıştır. Yapılan istatistiksel test sonucunda boyutların ikisinde de eğitim durumu değişkeni bakımından istatistiksel olarak anlamlı fark bulunmuştur. Farklılığın kaynağını belirlemek için Tukey testi uygulanmış, her iki boyutta da farklılığın ön lisans ile lisans mezunu gruplarının ortalamalarının farklı olmasından kaynaklandığı görülmüştür. Ortalamalar incelendiğinde, boyutların ikisinde de lisans mezunu çalışanların ortalamasının daha yüksek, Önlisans mezunu çalışanların ortalamalarının ise en düşük olduğu görülmektedir.

Tablo 6'de stres boyutlarının meslek değişkeni bakımından incelenmesi verilmiştir.

Tablo 6. Stres Boyutlarının Meslek Değişkeni Bakımından Incelenmesi

\begin{tabular}{|c|c|c|c|c|c|c|}
\hline & & $\mathrm{N}$ & Ort. & $\begin{array}{l}\text { Std. } \\
\text { Sapma }\end{array}$ & $F$ & $p$ \\
\hline \multirow[t]{4}{*}{ İş baskısı } & Hekim & 74 & 3,76 & 0,825 & 8,895 & $\begin{array}{l}0,000 \\
*\end{array}$ \\
\hline & Hemşire-ebe & 257 & 3,89 & 0,821 & & \\
\hline & $\begin{array}{l}\text { Sağlık teknisyeni- } \\
\text { teknikeri }\end{array}$ & 106 & 3,48 & 0,892 & & \\
\hline & Toplam & 437 & 3,77 & 0,855 & & \\
\hline \multirow[t]{4}{*}{$\begin{array}{ll}\text { Örgütsel } & \text { Destek } \\
\text { Eksikliği } & \end{array}$} & Hekim & 74 & 3,75 & 0,830 & 8,610 & $\begin{array}{l}0,000 \\
*\end{array}$ \\
\hline & Hemşire-ebe & 257 & 3,92 & 0,792 & & \\
\hline & $\begin{array}{l}\text { Sağlık teknisyeni- } \\
\text { teknikeri }\end{array}$ & 106 & 3,53 & 0,874 & & \\
\hline & Toplam & 437 & 3,79 & 0,833 & & \\
\hline
\end{tabular}

Stres ölçeği boyutlarının meslek değişkeni bakımından incelenmesi Tablo 6'da verilmiştir. Incelenen boyutlarda meslek değişkeni bakımından istatistiksel olarak anlamlı farklılık olup olmadığı ANOVA testi ile araştıııımıştır. Yapılan istatistiksel test sonucunda boyutların ikisinde de meslek değişkeni bakımından istatistiksel olarak anlamlı fark bulunmuştur. Farklılı̆ın kaynağını belirlemek için Tukey testi uygulanmış, her iki boyutta da farklıığın Hemşire-ebe ile Sağlık teknisyeni-teknikeri meslek gruplarının ortalamalarının farklı olmasından kaynaklandığı görülmüştür. Ortalamalar incelendiğinde, boyutların ikisinde de Hemşire-ebe çalışanların ortalamasının daha yüksek, sağlık teknisyeni-teknikeri çalışanların ortalamalarının ise en düşük olduğu görülmektedir.

\section{Tartışma}

Bu çalışmada, Şanlıurfa'nın Suriye sınııında bulunan ve Suriyeli göçmenler için oluşturulan kampların bulunduğu Suruç, Harran, Akçakale, Viranşehir ve Ceylanpınar ilçelerindeki Kamu Hastaneleri Kurumuna bağlı bulunan 5 devlet hastanesinde çalışan sağlık personelinin iş stres düzeyleri tespit edilmeye çalışılmıştır.

Mesleklerle ilgili olarak yapılan çalışmalarda gardiyanlık, polis memurluğu, öğretmenlik, ambulans şoförlüğü, hemşirelik, doktorluk, itfaiyecilik, diş hekimliği, askerlik gibi mesleklerin en stresli meslekler olduğu ileri sürülmektedir (20). Bunun yanı sıra yapılan araştırmalar, sağlık çalışanlarının şiddete uğrama riskinin diğer hizmet sektörü çalışanlarına oranla 16 kat daha fazla olduğunu, hemşirelerin ise diğer sağlık çalışanları arasında üç kat daha fazla risk altında olduğunu göstermektedir (21).

Araştırmamızda 5 en yüksek düzeyi ifade ettiği değerlendirildiğinde, hastanelerin ortalamalarına baktığımızda (tablo 2), tüm hastanelerdeki sağlık personelinin iş stres seviyesinin yüksek olduğunu görmekteyiz. Suriye sınırında bulunan Akçakale Devlet Hastanesinde çalışan sağlık personelinin ortalaması en yüksek, Ceylanpınar Devlet Hastanesinde çalışan sağlık personelinin ortalamasının ise en düşük ortalamaya sahip olduğu görülmektedir. Ceylanpınar Devlet Hastanesinde çalışan sağlık personelinin iş baskısı ve örgütsel destek eksikliği alt boyutlarının, diğer hastanelere göre düşük çıkması, araştırıması gereken bir konudur. Çünkü sınır bölgesine en yakın olan ilçelerden birisidir. Buraya, sınııın karşı tarafından bomba ve mermilerin atıldığı ve bazı vatandaşların atılan bu bomba veya mermilerden dolayı yaralandığı ve öldüğü görülmektedir. Ayrıca bu ilçedeki devlet hastanesi, diğer ilçe hastanelerine göre fiziki koşullar itibariyle eski ve yetersiz bir binaya sahiptir. Bu ve buna benzer olumsuz durumlara karşın, Ceylanpınar devlet hastanesinde çalışan sağlık personelinin is stres seviyesinin diğer ilçe hastanelerinde çalışan sağlık personeline göre daha düşük çıkması düşündürücüdür. Literatürde sağlık personelinin iş stres seviyesini belirlemek amacıyla yapılan araşıırmalarda, yaptığımız araştırma sonucuna benzer sonuçlar elde edildiğini görmekteyiz. Bu araştırmalarda da sağlık personelinin iş stresine maruz kaldıkları belirlenmiştir (10, 22- 26).

Araştırmaya katılan sağlık personeli yaş değişkeni bakımından incelendiğinde (Tablo 3 ), iş baskısı ve örgütsel destek eksikliği boyutlarının ikisinde de istatistiksel olarak anlamlı fark bulunmuştur. Farklılı̆ın kaynağını belirlemek için Tukey testi uygulanmış, her iki boyutta da farklıı̆ı̆ 
24 yaş ve altı ile 33 yaş ve üstü ve $25-27$ yaş ile 33 yaş ve üstü yaş gruplarının ortalamalarının farklı olmasından kaynaklandığı görülmüştür. 24 yaş ve altı grubun ortalamaları her iki boyutta da diğer yaş gruplarına göre daha yüksek çıkmıştır. Bu yaş grubundaki sağlık çalışanları genç ve deneyimsiz olmalarından ötürü iş stresine daha çok maruz kaldıkları görülmektedir. Bu araştırmanın aksine, literatürde sağlık çalışanlarının iş stres seviyeleri ile ilgili yapılan çalışmalar incelendiğinde, yaş itibariyle daha yaşlı olan sağık çalışanlarının iş stres seviyesinin, daha genç olan sağlık personeline göre anlamlı olarak daha yüksek çıktığı görülmektedir $(6,23,24,26,27)$.

Cinsiyet değişkeni bakımından (tablo 4), iş baskısı ve örgütsel destek eksikliği boyutların ikisinde de istatistiksel olarak anlamlı fark bulunmamasına karşın, cinsiyet açısından iş stres seviyesi yüksek çıkmıştır. İ̧ baskısı ve örgütsel destek eksikliği alt boyutlarında kadın sağlık personelinin ortalamalarının, erkek sağlık personeli ortalamalarından yüksek olduğu görülmektedir. Kadın personelin duygusal açıdan daha hassas olmalarının iş baskısı ve örgütsel destek eksikliği boyutlarında, erkek personele göre daha çok etkilendiklerini söyleyebiliriz. Literatürde yapılan bazı araştırmalarda bizim araştırma sonuçlarına benzer sonuç elde edilmiştir $(1,6,25,27,28)$. Bu çalışmalarda kadınların erkeklere göre, iş stresine karşı daha zayıf ve daha yoğun olarak maruz kaldıkları tespit edilmiştir. Literatürde bazı araştırmalarda cinsiyet değişkeni açısından anlamlı bir farklılık bulunmamış olmakla birlikte $(5,23)$, bazı araştırmalarda ise farkı sonuçlar elde edilmiş ve erkeklerin, kadınlara göre yüksek stres değerlerine sahip olmalarına rağmen istatistiksel olarak anlamlı bir fark bulunamamışıı $(24,26)$.

Araştırmaya katılan sağlık personelinin eğitim seviyeleri artııça iş stresine maruz kalma oranlarının arttığını görmekteyiz (tablo 5). Çalışan sağlık personelinin eğitim grupları açısından ortalamalarına baktığımızda, iş baskısı ve örgütsel destek eksikliği alt boyutlarında lisans mezunu grubundaki sağlık personelin ortalamalarının, diğer eğitim gruplarına göre daha yüksek değere sahip olduğu görülmektedir. Lisans mezunu grubundaki sağlık personelinin iş stresini, diğer eğitim grubunda çalışan personele göre daha çok hissettiklerini söylemek mümkündür. Ayrıca iş başkası ve örgütsel destek eksikliği alt boyutlarındaki ortalamalara bakıldığında önlisans mezunu grubunda yer alan sağlık personelinin ortalamalarının diğer gruplara göre en düşük ortalamaya sahip oldukları görülmektedir. Önlisans mezunu sağlık personelinin, diğer eğitim grubundaki sağlık personeline göre daha iş stresinden daha az etkilendikleri düşünülmektedir. Bu sonuçlara bakarak, eğitim seviyesi arttıkça, iş stresinden etkilenme oranının arttığını söyleyebiliriz.

Literatür taramalarında yapılan araştırma sonuçlarında farklı sonuçlar tespit edilmiştir. Yapılan bir araştırmada, bizim araştırma sonuçlarına benzer sonuçlar elde edilmiş ve stresin eğitim üzerinde önemli bir etkisi olduğu bildirilmiştir $(1,24,26)$. Literatür taramalarında yapıımış başka , bir araştırmada, bizim araştırmanın aksi doğrultuda sonuç elde edilmiş ve eğitim seviyesi düşük olan sağlık çalışanlarının iş stres seviyeleri, daha yüksek eğitimli sağlık çalışanlarına göre anlamlı derecede yüksek çıkmıştır (25). Başka bir çalışmada, lisansüstü mezunlarının iş stres seviyesinin diğer gruplara göre daha düşük; lisans mezunlarının ise daha yüksek stres seviyesine sahip olduğu belirlenmiştir (6).

Çalışan sağlık personelinin meslek grupları açısından ortalamalarına baktığımızda (tablo 6), iş baskısı ve örgütsel destek eksikliği alt boyutlarında hemşire-ebe grubundaki sağlık personelin ortalamalarının diğer meslek gruplarına göre daha yüksek olduğunu görmekteyiz. Hemşireebe grubundaki sağlık personelinin iş stres seviyesinin diğer meslek grubunda çalışan personele göre daha yüksek hissettiklerini söylemek mümkündür. Bunun yanı sıra iş baskısı ve örgütsel destek eksikliği alt boyutlarındaki ortalamalara bakıldığında sağlık teknisyeni-teknikeri grubunda yer alan sağlık personelinin ortalamalarının diğer gruplara göre en düşük ortalamaya sahip oldukları ve iş stresinden daha az etkilendikleri düşünülmektedir. Sonuç olarak çalışan sağık personelinin meslek gruplarının tamamının, iş stres seviyelerinin yüksek olduğunu tespit edilmiştir. Literatürde sağlık çalışanlarının iş stres seviyeleri ile ilgili yapılan çalışmalar incelendiğinde, mesleki açıdan hemşirelerin diğer sağık çalışanlarına göre daha yüksek oranda strese maruz kaldıkları tespit edilmiştir $(6,24,25,27,29)$. Bizim çalışmada da mesleki açıdan ortalamalar incelendiğinde, hemşirelerin, doktor ve sağlık teknisyenlerine oranla iş stresinden daha çok etkilendiklerini görmekteyiz. Literatürdeki bazı araştırmalarda ise hekimlerin, diğer sağlık çalışanlarına göre daha yüksek stres seviyesine sahip oldukları belirlenirken $(26,30)$, başka bir araştırmada ise sağlık teknisyenlerin ve teknikerlerin diğer çalışanlara göre stres seviyelerinin daha yüksek olduğu belirlenmişstir (31).

\section{Sonuç}

Araştırma, Şanlıurfa'nın Suriye sınırında bulunan ve Suriyeli göçmenler için oluşturulan kampların bulunduğu Suruç, Harran, Akçakale, Viranşehir ve Ceylanpınar ilçelerindeki Kamu Hastaneleri Kurumuna bağlı bulunan 5 devlet hastanesinde çalışan sağlık personelinin iş stres düzeylerini tespit etmek amacıyla yapılmıştır. Bu çalışma Türkiye'nin güney sınır bölgesinde yer alan ilçelerdeki hastanelerin tamamına genellenemez. Ancak bundan sonra yapılacak çalışmalar için veri teşkil edebilir. Ayrıca araştırmada sağlık personelinin kendi kişisel görüşleri esas alındığından, sağlık personelinin iş stres düzeylerinin sübjektif olarak ölçülmüş olması muhtemeldir.

Sonuç olarak araştırma yapılan hastanelerdeki çalışan sağık personelinin tamamının iş stres seviyesinin yüksek 
olduğu tespit edilmiştir. En çok etkilenen Akçakale devlet hastanesinde çalışan sağlık personeli olurken, en az etkilenen ise Ceylanpınar devlet hastanesinde çalışan sağlık personeli olduğu görülmektedir. Ayrıca araştırmaya katılan sağlık personelinin yaş, cinsiyet, eğitim ve meslek grupları değişkeni bakımından iş stres seviyesi yüksek çıkmışıı.

Bu araştırmada elde edilen bu veriler ışığında şu öneriler yapılabilir:

- Güvenlik birimleri tarafından, bu bölgedeki tüm vatandaşların can güvenliğinin sağlanması gerekmektedir. Bu ilçelerde görev yapan sağlık personeli, can güvenliği sağlandığı zaman, stresten uzak bir şekilde daha rahat çalışabilecektir.

- Hastane yönetimi tarafından sağlık personeli açısından stres yaratan faktörler tespit edilip, bunların ortadan kaldırıması için gerekli düzenlemeler yapılmalıdır.

- Hastane yönetimi tarafından, sağlık personeline iş stresine neden olan faktörleri tanıma, stresle baş etme yollarını öğrenme ve problem çözme becerilerini geliştirme konularında yardımcı olunmalıdır.

- Özellikle genç, bekar ve deneyimsiz olarak ilk kez bu bölgede çalışma hayatına başlayan genç sağlık çalışanlarına, çalışmaya başlamadan önce bölge hakkında bilgi verilmeli, çalışma koşulları, yapılan işin zorluğu ve riskleri, bölge insanı ile iletişim sağlama yöntemleri ile ilgili hizmet içi eğitimler verilmelidir.

- Bayan sağlık personeline pozitif ayrımcılık yapılarak, is stresi seviyelerini azaltacak uygulamalar hayata konulmalıdır.

- Sağlık kurumundaki iş yükü dikkate alınarak, personel ve malzeme yetersizliklerinin giderilmesine yönelik çaıışmalar yapılmalıdır. Mesai saatleri, dinlenmelerine ve özel yaşamlarına uygun olarak düzenlenmelidir.

- Sağlık personelinin, sağlık hizmeti sunumu esnasında karşılaş̧ıkları güçlükleri ve buna yönelik çözüm yollarını sunabilecekleri toplantıların belirli aralıklarla yapılması gerekmektedir.

\section{Kaynaklar}

1. Leca I, Tigu G. An Analysis Regarding The Factors That Generate Stress At Workplace: A Case Study In The Sales Force, Procedia Economics and Finance. 2015; (32): 680-5

2. Spielberger C.D, Reheiser E. C. Job Stress in University, Corporate, and Military Personnel, International Journal of Stress Management. 1994;1:19-31

3. Jamal M, Baba V.V. Job Stres And Burnout Among Canadian Managers And Nurses: An Empirical Examination. Can. J. PublicHealth. 2000;91(6): 454-8

4. Nelson T.Q. Stress Levels And Sources Of Occupational Stress Amoung PsiChı Faculty Advisors, Undergraduate Honors Theses Utah State University. 2009; Undergraduate Honors Theses. Paper 2

5. Erdoğan T, Ünsar AS, Süt N. Stresin Çalışanlar Üzerindeki Etkileri: Bir Araştırma, Süleyman Demirel Ûniversitesi İktisadi ve İdari Bilimler Fakültesi Dergisi Y. 2009;14 (2): 447-61.
6. Erşan E. E, Yıldırım G, Doğan O, Doğan S. Sağlık Çalışanlarının İş Doyumu Ve Algılanan İş Stresi İle Aralarındaki İlişkinin İncelenmesi, Anadolu Psikiyatri Derg. 2013;14:115-21.

7. Holmström S, Molander B, Jansson J. Barnekow-Bergqvist M. Evaluation of a Swedishversion of the Job Stress Survey, Scandinavian Journal of Psychology. 2008; 49: 277-86

8. Spielberger C.D, Vagg, P.R. Job Stress Survey: Professional Manual. Psychological Assessment Resources. Odessa, 1999.

9. Aslan S.H, Alparslan Z.N, Aslan R.O. İşe Bağı Gerginlik Ölçeğinin Sağlık Alanında Çalışanlarda Geçerlik ve Güvenirliği. Düşünen Adam.1998;11(2):4-8.

10. Tel H, Karadağ M, Tel H, Aydın Ş. Sağlık Çalışanlarının Çalışma Ortamındaki Stres Yaşantıları İle Baş Etme Durumlarının BelirIenmesi, Hemşirelikte Araştırma Geliştirme Dergisi. 2003; 2:13-23.

11. Bryant C, Fairbrother G, Fenton P. The Relative Influence of Personal and Work Place Descriptors on Stress. British Journal of Nursing. 2000; 9 (13): 876-80.

12. Mark G, Smith A.P. Occupational Stress, Job Characteristics, Coping, And The Mental Health Of Nurses, British Journal of Health Psychology. 2011;17 (3):505 -21.

13. Sullivan S.E, Bhagat R.S. Organizational Stress, Job Satisfaction And Job Performance: Where Do We Go From here? J Manag. 1992; 18 (2): 353-74.

14. Karabay M. E. Sağlık Personelinin İş Stresi, İ̧̧- Aile Çatışması Ve İs-Aile- Hayat Tatminlerine Yönelik Algılarının İşten Ayrılma Niyeti Üzerindeki Etkilerinin Belirlenmesi Üzerine Bir Araştırma, Yönetim Bilimleri Dergisi. 2015;13 (26);113-34.

15. AYTAÇ, S. İş Stresi Yönetimi El Kitabı: Oluşumu, Nedenleri, Başa Çıkma Yolları, Yönetimi, Labour Ministry-CASGEM Yayınevi. 2009

16. Sevgül Akgündüz, Örgütsel Stres Kaynaklarının Çalışanların İş Tatmini Üzerindeki Etkisi ve Banka Çalışanları Için Yapılan Bir Araştırma, Dokuz Eylül Üniversitesi Sosyal Bilimler Enstitüsü Yüksek Lisans Tezi, İzmir, 2006.

17. Sabuncuoğlu Z, Tüz. M. Örgütsel Psikoloji, Ezgi Kitabevi, Bursa, 1996; 197.

18. Cooper, C.L, Sloan S.J, William S. The Occupational Stress İndicator. NFER Nelson, Windsor. 1988.

19. Osipow S, Spokane A. Manual For Occupational Stress Inventory: Research Version. Psychological Assessment Resources, Odessa. 1987

20. Çınar O. Eğitim ve Sağık Alanı Çalışanlarının İş Stresi Düzeyleri. Elektronik Sosyal Bilimler Dergisi. 2010;9 (33): 101-21.

21. Kingma M. Work Place Violence In The Health Sector: A Problem Of Epidemic Proportion. IntNursRev.2001; 48: 129-30.

22. Schreiber James B, Nora A, Frances K, Stage, Elizabeth A. Barlow \& Jamie King. Reporting Structural Equation Modeling and Confirmatory Factor Analysis Results: A Review, Journal The Journal of Educational Research. 2006;99 (6): 323-38.

23. Tokmak $C$, Kaplan Ç, Türkmen $F$. İş Koşullarının Sağlık Çalışanlarında Yol Açtı̆̆ Stres Üzerine Sivas'ta Bir Araştırma, İ̧̧letme Araştırmaları Dergisi 2011: 3 (1); 49-68.

24. Atasoy A, Yorgun S. Sağlık Çalışanlarında İş Gerilimi ve İ̧̧ Stres Düzeyinin Değerlendirilmesi, Sağlıkta Performans ve Kalite Dergisi.2013; 6: 71-88.

25. Nam SJ, Chun HJ, Moon JS, Park SC, Hwang YJ, Yoo IK, et al. Job Stress and Job Satisfaction among Health-Care Workers of Endoscopy Units in Korea. Clin Endosc. 2016;49(3):266-72.

26. Koç Ş. R. Sağlık Çalışanlarında İş Stresi (Acil Servis Örneği), Beykent Üniversitesi Sosyal Bilimler Enstitüsü İşletme Yönetimi Anabilim Dalı Hastane Ve Sağlık Kurumları Yönetimi Bilim Dalı, İstanbul, 2009.

27. Jones MC, Wells M, Gao C, Cassidy B, Davie J, Work Stress And Well-Being In Oncology Settings: A Multidisciplinary Study Of Healthcare Professionals, Psycho-Oncology. 2013;22 (1): 46-53.

28. Korkmaz, M. Ceylan, B. Örgütsel Stres Yönetimi Ve Stresin İstanbul Büyükşehir Belediyesi Çalışanlarının İş Performansı Üzerine 
Etkisinin Uygulamalı Olarak İncelenmesi. Adıyaman Üniversitesi Sosyal Bilimler Enstitüsü Dergisi.2012;5(10):313-44.

29. Chou L, Li C, Hu S, Job Stress And Burnout In Hospital Employees: Comparisons Of Different Medical Professions in A Regional Hospital İn Taiwan, BMJ Open 2014; 4

30. Sehlen S, Vordermark D, Schäfer C, Herschbach P, Bayerl A, Pigorsch S, et al. Job Stress And Job Satisfaction Of Physicians, Radiographers, Nurses And Physicists working In Radiotherapy: A Multicenter an Alysis by the DEGRO Quality Of Life Workgroup, Radiation Oncology. 2009 4: 6

31. Kırımoğlu. S. Özel Bir Hastanede Görev Yapan Sağlık Çalışanlarının Güvenliğinin İş Stresine Etkisinin Araştırıması Gaziantep Üniversitesi Sosyal Bilimler Enstitüsü Iş Sağlığı Ve Güvenliği Anabilim Dalı, Gaziantep, 2017. 